\title{
A NEW CONCEPT OF WATER USE EFFICIENCY: A CASE STUDY FOR IRRIGATION SCHEMES IN BUYUK MENDERES BASIN
}

\author{
Cengiz Koc \\ Faculty of Architecture, Department of City and Regional Planning, Mugla \\ Sitki Kocman University, Mugla, Turkey. \\ Email:cengizko9@gmail.com
}

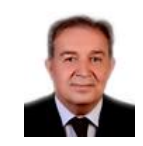

\section{Article History \\ Received: 6 January 2022 Revised: 9 February 2022 Accepted: 22 February 2022 Published: 4 March 2022 \\ Keywords \\ Irrigation \\ Irrigation efficiency \\ Salt load \\ Leaching \\ Water management \\ Buyuk Menderes basin \\ Turkey.}

\section{ABSTRACT}

Contribution/Originality: In this study, the efficiency of the water used in the irrigation schemes was calculated using the classical project, the developed classical and effective water use efficiency method. Effective water use efficiency takes into account the quantity and quality of water distributed in an irrigation scheme.

\section{INTRODUCTION}

Efficiency is defined as the ratio of useful output to total input in a system. The classical concepts of irrigation efficiency are suitable for farmers to make irrigation management decisions and for planners to design water conveyance and application systems. However, classical water use efficiency can cause incorrect decisions and wrong public policies in water basins as a whole [1, 2]. The management or design of irrigated fields in an irrigation system where the amount of water is the total input, is a matter of debate that should be addressed by both farmers and designers. Considering the amount of water as the total input is not a correct method for the water basin as a whole. As the water flows through a basin, it can be used several times. Therefore, the total input in each usage cycle constitutes only effectively used water. Classical concepts of efficiency do not consider flows returning from any application of systematically delivered irrigation water. For example, if the classical water use efficiency, which does not take into account the need for salt leaching, is $50 \%, 50 \%$ of the distributed water is lost in the atmosphere by plant evaporation and perspiration, and the other $50 \%$ re-enters the source with deep infiltration and surface flows. This returning flow is usually captured and reused at downstream by diverting structures or pumps. In this case, the irrigation system considered as a whole (basin) can have more water use efficiency than any other part. 
Conveyance, distribution and field water application losses constitute the total project water use efficiency. Therefore, total project efficiency varies over a wide range. Although the water use efficiency of the project is realized as $20 \%$ in Yemen, $28 \%$ in Thailand and $26 \%$ in Mexico, it can be $50 \%$ and higher in countries such as Cyprus and Israel where sprinkler and drip irrigation technologies are used with a piped system. Average total project activity for developing countries is $30 \%$. It ranges from $30 \%$ to $80 \%$ in the United States of America, an the national average is $41 \%[3,4]$. In Mediterranean region, project irrigation efficiencies range from 30 to $65 \%$, depending on the sophisticated of the irrigation system and the on-farm irrigation technology in use [5]. In the years of 1993-2018, the average project water use efficiency in irrigation schemes of State Agency (DSI) in Turkey is $44,2 \%[6]$. The key factors that influence project irrigation efficiency are how well the system is designed and how well the system is managed. Irrigation system design is the principal reason for lower than expected levels of efficiency [7].

A new concept, which we call effective water use efficiency, deals with the effects of each new cycle, the sequence of usage cycles, and the changes in water quality that occur during each usage cycle. This method focuses on the degradation of water resources caused by salt concentration and water use efficiency. In this study, the efficiency of irrigation water used during the 2019 irrigation season in Nazilli, Akçay, Aydın and Söke irrigation schemes located in the Büyük Menderes basin and connected to each other in terms of water resources was calculated and compared according to the classical project, developed classical and effective water use efficiency methods.

\section{MATERIALS AND METHOD}

\subsection{Material}

In this study, which aims to calculate with different methods the water use efficiency of Nazilli, Akçay, Aydın and Söke irrigation schemes built by DSI XXI Regional Directorate in the Büyük Menderes basin; the amount of water taken into the schemes, crop water consumption values determined according to the Blaney-Criddle method, ppm values of irrigation water, net irrigation areas, storage structures, water intake structures, and main canal flow rates were used. Data on irrigation water quality was obtained as a result of field study and evaluated under laboratory conditions. Table 1 presents data on the analyzed irrigation schemes [6, 8]. The average amount of precipitation for many years in Aydın, where irrigation schemes are located, is 646,5 mm, relative humidity $63 \%$, and temperature $17,7^{\circ} \mathrm{C}$. In the analyzed irrigation schemes, field crops, especially the cultivation of industrial crops, has an important place in agricultural production, as well as growing vegetables and fruits.

Table 1. Data on irrigation schemes examined in Büyük menderes basin [6, 8].

\begin{tabular}{|c|c|c|c|c|}
\hline Irrigation Schemes & Nazilli & Akçay & Aydın & Söke \\
\hline $\begin{array}{l}\text { Net crop water consuption } \\
\left(\mathrm{hm}^{3}\right)\end{array}$ & 104.24 & 32.88 & 65.88 & 137.94 \\
\hline Water taken into shemes $\left(\mathrm{hm}^{3}\right)$ & 241.00 & 79.83 & 107.83 & 243.25 \\
\hline Net irrigation ares (ha) & 15000 & 14900 & 14500 & 26000 \\
\hline Operated year & 1943 & 1965 & 1991 & 1982 \\
\hline Storage structures & Adıgüzel Dam & Kemer Dam & $\begin{array}{c}\text { Adıgüzel+Kemer } \\
\text { Dam }\end{array}$ & $\begin{array}{l}\text { Kemer+Çine } \\
\text { Dam }\end{array}$ \\
\hline Main canal flow rate $\left(\mathrm{m}^{3} / \mathrm{sn}\right)$ & Right:20-Left: 7.40 & Right:12- Left : 7.05 & 23.926 & 29.135 \\
\hline Water diversion structures & Regulator & Regulator & Regulator & Regulator \\
\hline $\begin{array}{l}\text { Irrigation water salt load } \\
(\mathrm{ppm})\end{array}$ & 832 & 365 & 563 & 640 \\
\hline Returning flow salt load (ppm) & 1440 & 750 & 1063 & 1600 \\
\hline Outflow salt load (ppm) & 1120 & 563 & 768 & 0.00 \\
\hline
\end{tabular}

Irrigation water required for irrigation schemes is provided from Adıgüzel, Kemer and Çine dams. Adıgüzel dam is a rock fill dam in the north of Güney district of Denizli province, and important water resources for storage are 
Banaz Stream, Hamam Stream and Işıklı Lake. The Kemer dam was built on Akçay and is for irrigation and energy purposes [9].

\subsection{Method}

In order to determine the water use efficiency of the studied basin irrigation schemes, classical project, developed classical and efficient water use efficiency methods were used. Calculations were made with Microsoft Office 2000 Excel computer program.

\subsubsection{Classic Project Irrigation Efficiency}

The literature on irrigation includes many classic water use efficiency concepts. Israelsan [10] defines the basic concept of irrigation efficiency $\left(\mathrm{E}_{\mathrm{c}}\right)$ as the ratio of water consumed by crops $\left(\mathrm{U}_{\mathrm{ci}}\right)$ to water $\left(\mathrm{V}_{\mathrm{D}}\right)$ distributed from surface or underground sources to field canals.

$$
\mathrm{E}_{\mathrm{c}}=\frac{\text { Irrigation water evaporated by crops }}{\text { Irrigation water applied, distributed or diverted }}=\frac{\mathrm{U}_{\mathrm{ci}}}{\mathrm{V}_{\mathrm{D}}}=\frac{\mathrm{ET}_{\mathrm{B}}-\mathrm{P}_{\mathrm{e}}}{\mathrm{V}_{\mathrm{D}}}
$$

$\mathrm{E}_{\mathrm{TB}}$ is evapotranspiration and $\mathrm{P}_{\mathrm{e}}$ is effective rainfall. This first concept of efficiency, accepted by world irrigationers is a suitable for agricultural irrigation designers but, limited indicator. It applicates the amount of water that must be managed to meet the estimated amount of useful use. Its use is limited for design purposes as it neglects the required leaching water.

\subsubsection{Developed Classic Irrigation Efficiency}

When irrigation water is lost through transpiration by crops and evaporation from the soil surface, salt is left behind and accumulates in the soil. Maintaining an appropriate salt balance for optimal crop production requires to be washed from the soil profile of the remaining salts by excessive water application at specific time intervals. The minimum amount of irrigation water application that should infiltre under the root zone in order to maintain a suitable salt balance is defined as $\mathrm{V}_{\mathrm{LR}}$, leaching water requirement ratio $\mathrm{L}_{\mathrm{R}}[11,12]$.

$\mathrm{LR}=\frac{V_{L R}}{\mathrm{U}_{\mathrm{ci}}+\mathrm{V}_{\mathrm{LR}}}$

Since the crops have different resistance to soil salinity, the quality of irrigation water and the amount of leaching water required by each crop are different. It is also a function of soil texture, repetition of irrigation and irrigation water application method. Leaching water requirements for different crops and irrigation water qualities were researched and documented by Ayers and Westcot [13]. As a result, the classical concept of irrigation efficiency given in Equation 1 was expanded to explain the leaching water requirements.

$$
\begin{aligned}
\mathrm{E}_{\mathrm{dc}}=\frac{\mathrm{E}_{\mathrm{c}}}{(1-\mathrm{LR})} \\
\mathrm{E}_{\mathrm{dc}}=\frac{\left(\mathrm{ET}_{\mathrm{B}}-\mathrm{P}_{\mathrm{e}}\right)+\mathrm{V}_{\mathrm{LR}}}{\mathrm{V}_{\mathrm{D}}}=\frac{\mathrm{U}_{\mathrm{ci}}+\mathrm{V}_{\mathrm{LR}}}{\mathrm{V}_{\mathrm{D}}}=\frac{\mathrm{U}_{\mathrm{ci}}}{(1-\mathrm{LR}) \mathrm{V}_{\mathrm{D}}}
\end{aligned}
$$

Irrigation engineers using the classical irrigation efficiency concept have made an intense effort to overcome some problems. Classical irrigation efficiency; uniformity of application, effective rainfall and its relationship with real crop evapotranspiration forecast; What is the use of correct and beneficial water meeting the 
evapotranspiration and leaching water requirement; application values for conveyance losses, salt leaching requirements, meeting evapotranspiration potentials, irrigation frequency and how the relationship should be with the irrigation schedule have not yet been explained fully.

\subsubsection{Efficient Irrigation Efficiency}

Jensen [14] and Jensen, et al. [15] stated that classical water use efficiency is often misapplied in developing the water resources as it does not consider the improvement of irrigation water. Jensen [14] stated the concept of net irrigation efficiency for water resources management purposes. Jensen [14] proposed the concept of net irrigation efficiency for management goals of water resources.

$$
\mathrm{E}_{\mathrm{N}}=\mathrm{E}_{\mathrm{c}}+\mathrm{E}_{\mathrm{R}}\left(1-\mathrm{E}_{\mathrm{c}}\right)
$$

Here, Ec is the classic project water use activity stated by Israelsan [10]. $\mathrm{E}_{\mathrm{R}}$ is a part of the water which does not evaporate and can be used in irrigation again. For this reason, Equation 5 does not take into account the leaching water requirements or salt effects created by the returning flows. The concept of efficient water use efficiency, together with the concept of efficient resource use, goes beyond the limitations of the classical efficiency approach with Equation 5. Including the water quality of strategic researches to conserve water resources provides a meaningful and useful tool from the macro and micro perspectives. The amount of real resource that can directly meet the useful consumption usage is the effective resource. Irrigation water consumed by crop evapotranspiration and evaporation leaves concentrated salt and remaining water. Some parts of the water source (leaching requirement, LR) should be leached from the crop root zone to ensure acceptable soil salinity. If the planted crop pattern is salt-sensitive and the water source contains too much salt, a higher leaching rate (LR) is required to leach the salt.

$$
\mathrm{V}_{\mathrm{e}}=(1-\mathrm{LR}) \mathrm{V}
$$

The actual water use $(\mathrm{U})$ for a zone is the difference between the flow entering the zone and the outgoing flow that can be improved or reused in the zone. Similarly, the effective water use (Ue) for a region consists of the difference between the effective inflow (Vei), and the effective outflow (Veo).

$$
\mathrm{E}_{\mathrm{e}}=\frac{\mathrm{U}_{\mathrm{ci}}}{\mathrm{U}_{\mathrm{e}}}=\frac{\mathrm{U}_{\mathrm{ci}}}{\mathrm{V}_{\mathrm{el}}-\mathrm{V}_{\mathrm{eo}}}=\frac{\mathrm{ET}_{\mathrm{B}}-\mathrm{P}_{\mathrm{e}}}{\left(1-\mathrm{LR}_{\mathrm{I}}\right) \mathrm{V}_{\mathrm{I}}-\left(1-\mathrm{LR}_{\mathrm{o}}\right) \mathrm{V}_{\mathrm{o}}}
$$

Here, $\mathrm{i}$ is the inflow and o is the outflow. In other words, effective water use efficiency is the efficiency of a system that is explained with the amount of water effectively consumed by the system.

\section{RESEARCH FINDINGS AND DISCUSSION}

Water use efficiencies of Nazilli, Akçay, Aydın and Söke irrigation schemes, which are located in the Büyük Menderes basin and whose constructions were completed by DSI and transferred to the irrigation associations, were calculated according to the project classic, improved classical and effective irrigation efficiency methods, and the values obtained are shown in Table 2 and Figure 1. Equation 1, 4 and 7 were used to determine the water use efficiency of the analyzed irrigation schemes. The basin irrigation schemes take the irrigation water through the regulators constructed on Büyük Menderes river and its tributaries. The water returning from irrigation in the irrigation schemes constitutes the water source of the consecutive irrigation scheme. Salt concentrations of inlet flow $\left(\mathrm{V}_{\mathrm{i}}\right)$ in the analyzed irrigation schemes were measured as 832, 365, 563 and 640 ppm for Nazilli, Akçay, Aydın and Söke irrigation schemes, respectively. The salt amount of irrigation water diverted to irrigation schemes was calculated as $0,832 \mathrm{~kg} \cdot \mathrm{m}^{-3}$ in Nazilli irrigation scheme and $0.64 \mathrm{~kg} \cdot \mathrm{m}^{-3}$ in Söke irrigation scheme. In the basin irrigation schemes, the irrigation water quality of the flows entering the system is $\mathrm{C}_{2} \mathrm{~S}_{1}$. Considering the salt density of the flows entering the irrigation schemes and the grown plant patterns, the leaching water requirement of the inflows is $16.6 \%$ in Nazilli scheme, $7.13 \%$ in Akçay scheme, $11.27 \%$ and $13 \%$ in Aydın and Söke schemes. 
Effective inflow $\left(\mathrm{V}_{\mathrm{ei}}\right)$ for Nazilli scheme, 100-16,62 = 83.40\%; It is 92.87\%, 83.73\% and 87\% in Akçay, Aydın and Söke schemes. Based on the amount of water stored in dams during the season, the amount of water diverted to the schemes is 32.13\%, 36.39\%, 29.95\% and 100\% for Nazilli, Akçay, Aydın and Söke. The salt load of the flows returning from irrigation increases up to $1600 \mathrm{ppm}$ in the irrigation schemes. The salinity of the river arising from the downstream movement of the flows entering the river again after being used in irrigation, in other words, the outflow $\left(\mathrm{V}_{\mathrm{eo}}\right)$, rises up to $1120 \mathrm{ppm}$ at the downstream of the Nazilli scheme, and the salt load of the outflow increases by $36.4 \%$ according to the inflow. The leaching water requirement of the outflow from Nazilli, Akçay, Aydın schemes was determined as $22.06 \%, 11.27 \%$ and $15.14 \%$, respectively. The application stages of the mentioned method to Nazilli irrigation network are given below.

Table 2. Calculation and comparison of classical project, developed classical and efficient water use efficiency in Büyük Menderes basin irrigation schemes ${ }^{1}$.

\begin{tabular}{|c|c|c|c|c|}
\hline Irrigation Schemes & Nazilli & Akçay & Aydin & Söke \\
\hline \multicolumn{5}{|l|}{ Inflow } \\
\hline Water resource $\mathrm{V} 1\left(\mathrm{~m}^{3}\right)$ & $750 \times 10^{6}$ & $350 \times 10^{6}$ & $400 \times 10^{6}$ & $235 \times 10^{6}$ \\
\hline Salt (ppm) & 832 & 365 & 563 & 640 \\
\hline Leaching water, $\mathrm{LR}_{1}{ }^{2}$ & 16.62 & 7.13 & 11.27 & 13.00 \\
\hline Efficient resource, $\mathrm{V}_{\mathrm{el}}$ (\% of flowing) & 83.4 & 92.87 & 88.73 & 87.00 \\
\hline Diverted Water, (\% Of Flowing) & 32.13 & 36.96 & 26.95 & 100 \\
\hline \multicolumn{5}{|l|}{ Net Water Consumption } \\
\hline Agricultural area, $\mathrm{U}_{\text {ci }}(\% \text { of flowing })^{3}$ & 13.00 & 16.02 & 15.47 & 58.00 \\
\hline Drain area plants (\% of flowing) & 0.89 & 0.79 & 1.00 & 1.25 \\
\hline Total (\% of flowing) & 13.89 & 16.81 & 16.47 & 59.25 \\
\hline \multicolumn{5}{|l|}{ Returning Flow from Irrigation } \\
\hline Water, (\% of flowing) & 18.24 & 20.15 & 10.48 & 40.75 \\
\hline Salt (ppm) & 1440 & 750 & 1063 & 1600 \\
\hline Improving (\% of Returning flow) & 100 & 100 & 100 & $\mathrm{O}$ \\
\hline \multicolumn{5}{|l|}{ Outflow } \\
\hline Water, $\mathrm{V}_{\mathrm{o}}$ (\% of flowing) & 86.11 & 83.19 & 83.53 & $\mathrm{O}$ \\
\hline Salt (ppm) & 1120 & 563 & 768 & - \\
\hline Leaching water, $\mathrm{LR}_{\mathrm{o}}{ }^{2}$ & 22.06 & 11.27 & 15.41 & - \\
\hline Efficient outflow, $\mathrm{V}_{\text {eo }}$ (\% of flowing) & 67.11 & 73.81 & 70.66 & $\mathrm{O}$ \\
\hline Efficient Using $\mathrm{U}_{\mathrm{e}}(\%$ Of Flowing) & 16.27 & 19.05 & 18.07 & 87.00 \\
\hline \multicolumn{5}{|l|}{ Efficiency } \\
\hline Developed Classic Efficiency, $\mathrm{E}_{\mathrm{dc}}$ & 0.49 & 0.47 & 0.65 & 0.67 \\
\hline Efficient Efficiency, $\mathrm{E}_{\mathrm{e}}$ & 0.80 & 0.84 & 0.86 & 0.67 \\
\hline Classic Efficiency, $\mathrm{E}_{\mathrm{c}}$ & 0.43 & 0.45 & 0.61 & 0.59 \\
\hline
\end{tabular}

1. The water source of Nazilli irrigation scheme, where $32.13 \%$ of the total flow is diverted from Büyük Menderes river with the Feslek regulator, has an average salt density of $832 \mathrm{ppm}$. For a complex crop pattern cultivated within the scheme in the current water quality, the leaching water requirement $\left(\mathrm{LR}_{\mathrm{i}}\right)$ of inflowing is $16.62 \%$. The actual inflow or effective source $\left(\mathrm{V}_{\mathrm{i}}\right)$ is $(100-16.62 \%) 83.4 \%$. This value is defined as the effective flow $\left(\mathrm{V}_{\mathrm{ei}}\right)$, or effectively usable resource at the point where the Büyük Menderes river reaches the Nazilli scheme.

2. As the flows returning from irrigation in the Nazilli scheme move towards the downstream of the Büyük Menderes river from the end point of the network, the river salinity reaches $1120 \mathrm{ppm}$. The leaching requirement $\left(\mathrm{LR}_{\mathrm{o}}\right)$ of the outflow is approximately $22.06 \% .77 .94 \%(100-22.06 \%)$ of the actual outflow $\left(\mathrm{V}_{\mathrm{o}}\right)$ gives the effective outflow $\left(\mathrm{V}_{\mathrm{eo}}\right)$.

3. Considering the stages 1 and 2, the effective use $\left(\mathrm{U}_{\mathrm{e}}\right)$ for the Nazilli scheme is calculated by subtracting of $77.94 \%$, which is the river flow at downstream of the point where the flows returning from irrigation enter the river from $83.40 \%$ of the river flow at the upstream of the point where the water is diverted to the irrigation scheme. The volume of actual or evaporating water within the irrigation area service area is $13.89 \%$ of the Büyük Menderes river 
flows in that region. Crops planted in the irrigation area use $13 \%$ of the water resource, and groundwater plants and useless evaporation consume 0.89\%. Effective usage is $\mathrm{U}_{\mathrm{e}}=(83.40-100 \%)-[(100-22.06 \%) \mathrm{x}(100-13.89 \%)]=16.27 \%$, as all of the flow returning from the irrigation scheme is reappeared along the downstream route of the river. In addition to the actual consumption of $13.89 \%$ by evaporation and evapotranspiration in the irrigation scheme, $2.38 \%$ $(16.27-13.89 \%)$ of the river freshwater is effectively lost due to salt concentration and accumulation. A small amount of fresh water consumption in this equation is due to the concentration of salts remaining after consumption by evaporation or evapotranspiration. Most of this is caused by salt accumulation in the returning flow.

4. Based on the values calculated above, the effective irrigation efficiency for Nazilli irrigation scheme is $\mathrm{E}_{\mathrm{e}}=13.00 / 16.27=80 \%$.

5. In the calculation of the developed classical irrigation efficiency regarding the irrigation scheme, the amount of water consumed by adding of required leaching water volume for crops to the diverted flow to irrigation is divided by the irrigation area total crop water consumption. $\mathrm{U}_{\mathrm{ci}}+\mathrm{V}_{\mathrm{LR}}=\mathrm{U}_{\mathrm{ci}} /(1-\mathrm{LR})=13.00 \% /(100 \%-16.62 \%)=15.59 \%$, and the improved classical irrigation efficiency is $\mathrm{E}_{\mathrm{dc}}=15.59 \% / \% 32.13=49 \%$.

6. Classical project irrigation efficiency is obtained by dividing the calculated plant water consumption value $\left(\mathrm{U}_{\mathrm{ci}}\right)$ to the diverted flow $\left(\mathrm{V}_{\mathrm{D}}\right)$, regardless of the leaching water requirement. Classical project water use efficiency for Nazilli scheme was calculated as $\mathrm{E}_{\mathrm{c}}=13.89 \% / 32.13 \%=43 \%$.

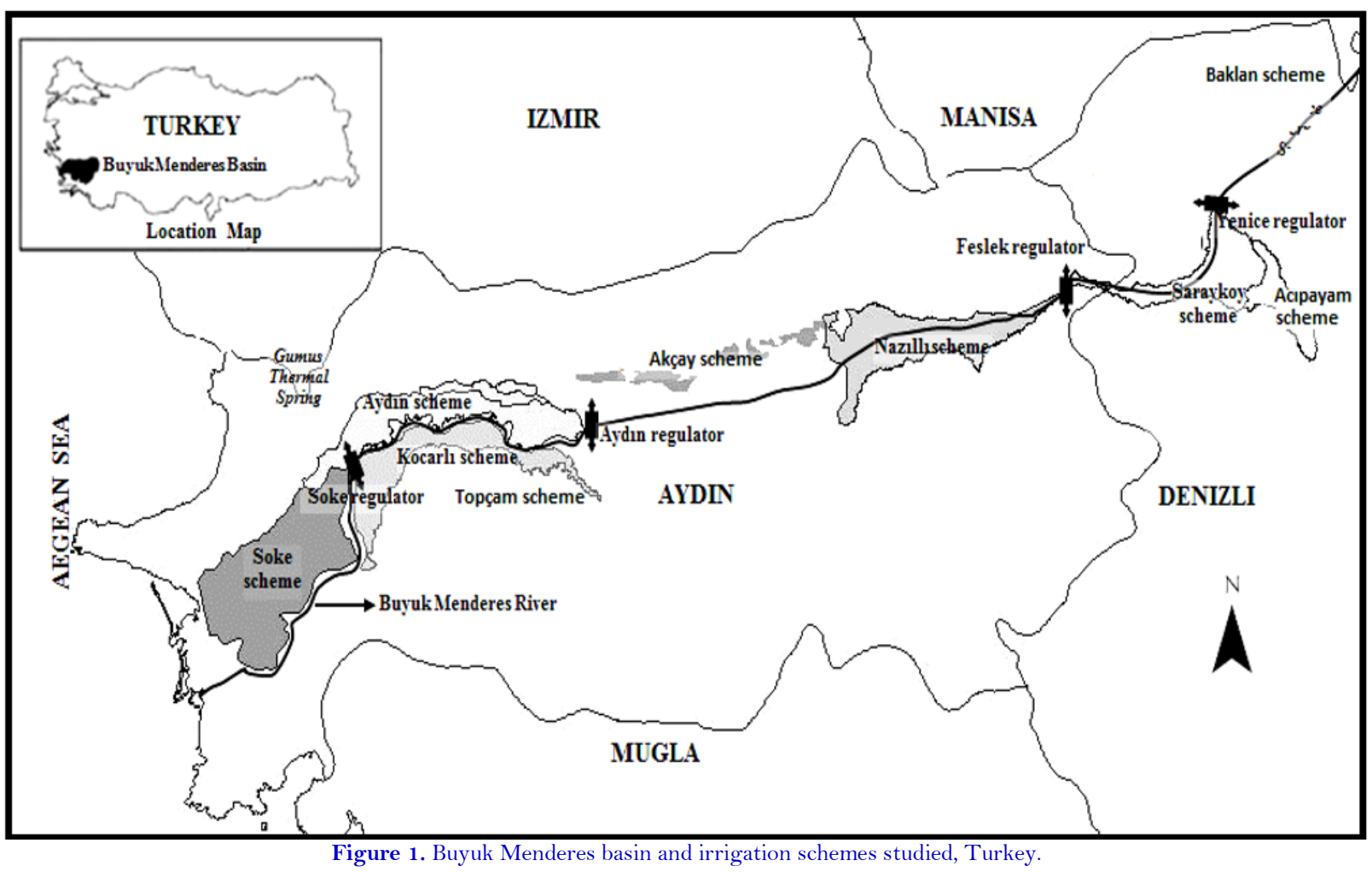

As can be seen in Figure 1, the classical project, developed classical irrigation efficiencies of the examined irrigation schemes are realized at values close to each other. The classical project, developed classical project and efficient efficiency values for the basin irrigation schemes are calculated and presented in Figure 2. Efficient water use efficiency was realized at very high values. Considering the classical project efficiency in Nazilli, Akçay, Aydın and Söke irrigation schemes, a significant amount of irrigation water is not used. In the analyzed irrigation schemes, $57 \%$ of water in Nazilli, 55\% in Akçay, 39\% in Aydın, and 41\% in Söke are not used. In other words, about 
$48 \%$ of the diverted water is required to meet plant needs. In the irrigation schemes, the rate of classical project water use inefficiency is $57 \%, 55 \%, 39 \%$ and $41 \%$, respectively.

Effective water use efficiencies were realized as 80, 84, 86 and 67\% in Nazilli, Akçay, Aydın and Söke schemes, respectively. Since the irrigation schemes are sequential systems, the outflow from one system constitutes the water source of the other system. In the effective water use efficiency method, the irrigation schemes consider the amount of leaching water to be used to leach of the salt which may accumulate in the soil profile apart from the crop water requirement. $2,38 \%$ of the irrigation water diverted to the Nazilli scheme was used for salt leaching. The amount of irrigation water used for salt leaching in the Akçay, Aydın and Söke irrigation schemes was calculated as 2,24\%, 1,60\% and 27,75\%. Average effective water use in Nazilli, Akçay and Aydın irrigation schemes is 17,80\%. Söke scheme has a single cycle system. Water returning from irrigation is not used in the next irrigation system, only a cyclical water use is realized within its own irrigation area. Therefore, Ec = Ee was realized as 67\% in Söke scheme. Since Büyük Menderes basin has the feature of a partially closed basin, a significant amount of the flows entering the irrigation schemes in the summer months returns Büyük Menderes river again as the outflow of the schemes and forms the additional water source for the next irrigation system. The discharge of sewage and industrial wastes of Denizli Province Organized Industry and Sarayköy District into the upstream route along of Büyük Menderes river, causes an increase in the salt density of the irrigation water diverted from the regulator to the Nazilli scheme.

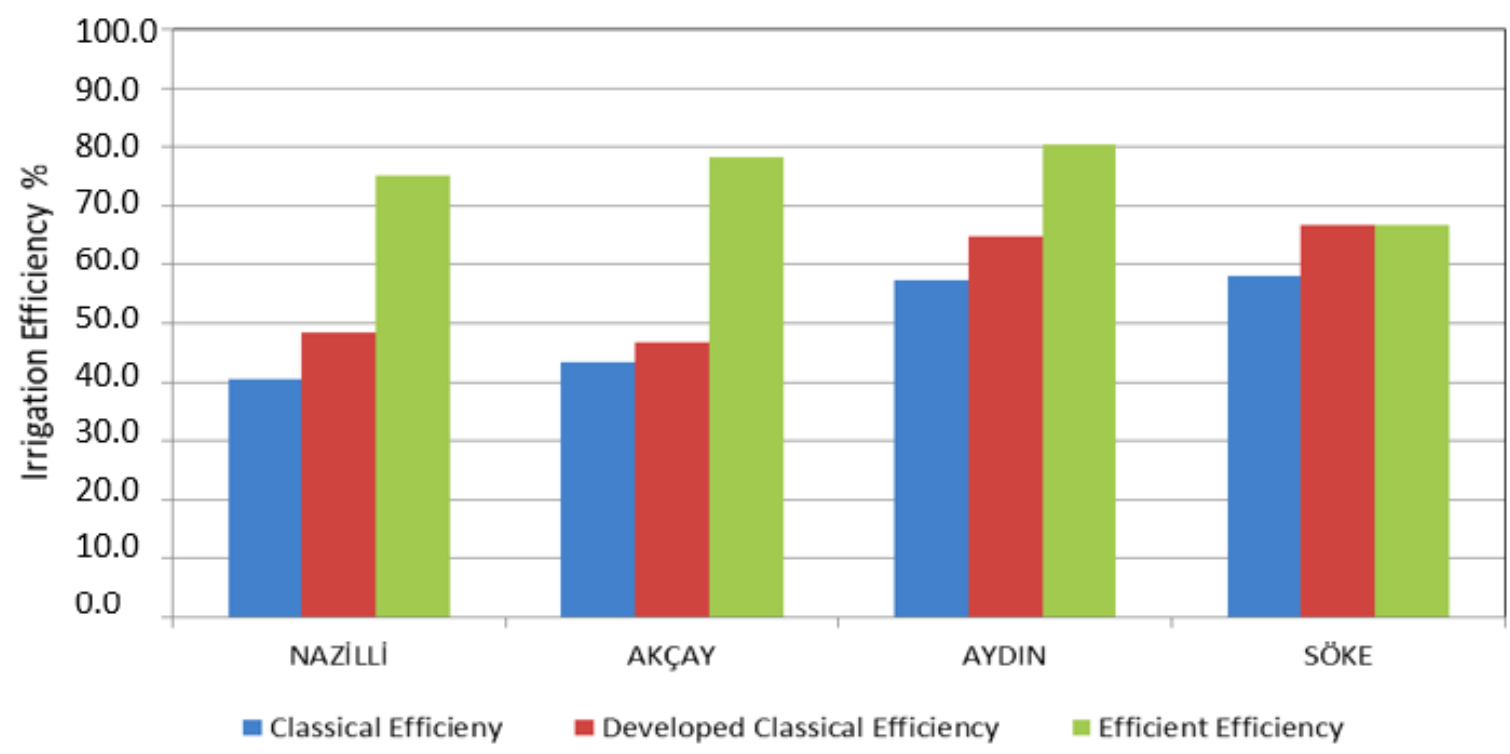

Figure 2. Classic, developed, and efficient efficiencies in irrigation schemes of Buyuk Menders Basin.

\section{CONCLUSION AND RECOMMENDATIONS}

Irrigation development planning studies focus on the amount of water consumed in the initial phase, and efforts are made to optimize the system by focusing less on other issues. Classical irrigation efficiencies based on the amount of water used do not explain the extent of water use, they are only used to evaluate the macro level or regional performance. Conventional water use efficiency concepts are suitable for irrigation management and irrigation design. However, it is not suitable for decision-making regarding water allocation and transfer policies. Efforts to increase water use efficiency based on classical water use efficiency calculations generally do not result in real water savings. For this reason, many planners misjudge and mislead irrigation improvement projects designed to improve the classic irrigation efficiency of a system that they expect will produce real water savings.

Classical irrigation efficiency is enhanced by reducing flows returning from operating losses at field level. To increase the classical irrigation efficiency should be taken measures such as reducing the deep seepage losses, carefully determining the soil structure and profile depth at the project stage, comparing the evaporation and evapotranspiration calculations according to several different methods, avoiding from design and project planning 
errors in irrigation structures, eliminating the water control deficiencies in night and weekend irrigations, inadequacy and weakness in management, climate patterns and accurate determination of effective rainfall and improvement of the water application method used.

Effective water use efficiency is proposed as a new concept in deciding on water resources in order to overcome the limits of classical water use efficiency. Effective water use efficiency takes into account the amount and quality of water returned to water source of a basin and distributed when estimating the total freshwater input for a freshwater use cycle. When classical and effective water use efficiencies are examined, four important factors emerge. If the outflows in the effective water use efficiency are negative or zero, the calculated effective water use efficiency is equivalent to the classical efficiency $\left(\mathrm{E}_{\mathrm{c}}=\mathrm{E}_{\mathrm{e}}\right)$. Some of the conditions in which effective water use efficiency is equal to classical water use efficiency are given below:

- Irrigation in salty areas and regions where the flows returning from irrigation are so salty that they cannot be used in a new usage cycle [2].

- Places where irrigation or other uses of water occur close to salty seas and excessive flow directly discharges into the seas.

- The occurrence of severe imbalances between the water supply and demand at certain times and places, and the outflows occurring at the wrong place and time in the system.

- Especially, places where the outflow in arid areas goes to superficial lakes, where the water evaporates very little due to any benefit.

High classical water use efficiency occurs in samples where such conditions occur. However, effective water use efficiency formulas include these examples as well as other examples of beneficial reuse of the outflows. Although the classical concept of efficiency plays an important role in the design and management of water distribution systems, effective water use efficiency is not considered appropriate for these purposes.

In all definitions of efficiency, precipitation is included in the analysis only as effective precipitation $\left(\mathrm{P}_{\mathrm{e}}\right)$. The difference between the total precipitation $\left(\mathrm{P}-\mathrm{P}_{\mathrm{e}}\right)$ is considered to be the amount of ineffective precipitation. Most of the water losses in classical efficiency are lost in the system. This situation does not comply with the water balance of the hydrological system as a whole. The classical and effective formulas of effectiveness do not take into account the value sharing for the amount and flow of water, but are based on the fact that the flows remain within the physical region only. When words such as efficiency are used, value assessments should be important elements of the underlying concepts. A distinction must be made between water flows as beneficial or unhelpful (zero or negative). Since the net benefit in classical efficiency is evaporation, there is no significant problem. However, formulas for effective water use efficiency reveal a major problem, as flows show negative or zero effects in samples with oversaturation and salinity. A complete distinction cannot be made between the amount of water consumed and not consumed in effective use efficiency formulas. Therefore, it is important to determine the flows that are improved and outflows in net and efficient water use efficiency concepts. The ultimate goal in water resources policy and management is to increase the useful use of water, and there are six basic elements to fulfill this.

- To improve the remaining water resources with technical and institutional methods in open or closed basin examples, in regions where the existing water resources at basin level are utilized [1, 17].

- To reduce useless flow rates to unhelpful evaporation and discharges.

- Increasing the benefit amount of each unit of beneficial evaporation with the useful flow rate for discharges.

- To reduce water pollution, water saturation and flood damage.

- Reallocating water from lower to higher value uses.

Funding: This study received no specific financial support.

Competing Interests: The authors declare that they have no competing interests.

Authors' Contributions: All authors contributed equally to the conception and design of the study. 


\section{REFERENCES}

[1] C. Koç, "Irrigation and drainage systems research and development in XXI century," presented at the International Symposium Water for Development Worldwide, 07-11 September, Istanbul, Republic of Turkey Ministry of Energy and Natural Resources General Directorate of State Hydraulic Works, İstanbul, Turkey, 2005.

[2] C. Koç, "The environmental effects of salinity load in Great Menderes Basin irrigation schemes," Environmental Monitoring and Assessment, vol. 146, pp. 479-489, 2008.Available at: https://doi.org/10.1007/s 10661-008-0478-0.

[3] Anonymous, Water resources and environment technical not E1. Irrigation and drainage development. Washington, USA: The World Bank, 2002.

[4] C. Koç, "A study on some parameters which can affect project irrigation efficiency in irrigation networks," Irrigation and Drainage, vol. 62, pp. 586-591, 2013.Available at: https://doi.org/10.1002/ird.1754.

[5] A. Hamdy, "Water use efficiency in irrigated agriculture: An analytical review," Options Méditerranéennes. Series B, No. 57, pp. 9-19, 2007.

[6] DSI (State Hydraulic Works), "Irrigation and drainage facilities operated and constructed by DSI," ed Ankara: Ministry of Environment and Forestry, General Directorate of State Hydraulic Works (DSI), Department of Operation and Maintenance, 2019, p. 324.

[7] Lincoln Environmental (LE), "Mid-Canterbury water resources development investigation - stage I," Report No 4418/1, Prepared for Ashburton Community Water Trust. Lincoln Environmental, a division of Lincoln Ventures Ltd, 2000 .

[8] D. S. H. Works), "DSI general directorate XXI regional directorate, operation and maintenance branch Office records," XXI. Regional Directorate of State Hydraulic Works, Aydın, Turkey, 2003.

[9] C. Koç, "A study on the role and importance of irrigation management in integrated River Basin management," Environmental Monitoring and Assessment, vol. 187, pp. 1-20, 2015.Available at: https://doi.org/10.1007/s 10661-015$4647-7$.

[10] W. O. Israelsan, Irrigation principles and practices. New York: Wiley, 1950.

[11] J. Keller, N. S. Peabody, D. Seckler, and D. Wichelns, "Water policy innovations in California: Water resource management in a closing water system," Center for Economic Policy Studies Discussion Paper No. 2 Arlington, Virginia: Winrock International 1990.

[12] J. Keller, "Implications of improving agricultural water use and efficiency on Egyp's water and salinity balances," Center for Economic Policy Studies Discussion Paper No. 6. Arlington, Virginia: Winrock International1992.

[13] R. Ayers and D. Westcot, Water quality for agriculture. FAO irrigation and drainage Paper No. 29, Rev1 ed. Rome: FAO, 1985.

[14] M. E. Jensen, "Water conservation and irrigation systems," in Proceeding of the Climate- Tecnology Seminar, 208-50. Colombia, Missure, 1977.

[15] M. Jensen, D. Harrison, H. Korven, and F. Robinson, "The role of irrigation in food and fiber production," The Role of Irrigation in Food and Fiber Production, pp. 15-41, ref.61, 1980.

[16] M. Ayyıldız, Irrigation water quality and salinity problems. Ankara: Ankara University, Faculty of Agriculture, Department of Agricultural Structures and Irrigation, Textbook, 1983.

[17] C. Koç, "A study on planned and applied irrigation modules in irrigation networks: A case study at Büyük Menderes Basin, Turkey," Computational Water, Energy, and Environmental Engineering, vol. 5, pp. 112-122, 2016.Available at: https://doi.org/10.4236/cweee.2016.54011. 